\title{
Examining the Effect of Microcredit on Employment in Peninsular Malaysia
}

\author{
Abdullah- Al- Mamun (Corresponding author) \\ Centre for Social Entrepreneurship, Binary University College, 47100 Puchong, Malaysia \\ Tel: 60-16-215-7752_E-mail: mamun.freethinker@gmail.com, abdullah@binary.edu.my \\ Sazali Abdul Wahab \\ National Defence University of Malaysia, Kuala Lumpur, 57000, Malaysia \\ Tel: 60-3-9051-3060 E-mail: saw@upnm.edu.my \\ C. A. Malarvizhi \\ Faculty of Management, Multimedia University, 63100 Cyberjaya, Malaysia \\ Tel: 60-3-8312-5679 E-mail: malarvizhi@mmu.edu.my
}

Received: November 3, 2010

Accepted: December 20, 2010

doi:10.5539/jsd.v4n2p174

\begin{abstract}
This study employs a cross sectional design with stratified random sampling method to examine how participation in Amanah Ikhtiar Malaysia's (AIM) microcredit program affects employment rate of hardcore poor clients household and community in Peninsular Malaysia. So far no known study has been conducted to measure the effect of AIM's microcredit program on employment. Findings of this study show that participation in AIM's microcredit program increases employment generating opportunities at household and community level. The policy may be reviewed and re-organized to increase the employment rate and income generating opportunities by providing appropriate training and diversified and flexible loan offers.
\end{abstract}

Keywords: Microcredit, Employment, Hardcore Poor, Amanah Ikhtiar Malaysia

\section{Introduction}

Development economists have long agreed that access to finance plays an essential role in the process of reducing the inequality in income distribution, enhancing the household income and employment of the poor and hardcore poor households all over the world. The poor and hardcore poor households commonly have little or no land, little education, no specialized skills and almost zero working capital. The group based microcredit program provides small amount of credit as working capital and training the poor and hardcore poor households, which all together contributes to both self and wage employment (Neill et al., 1994; Khandker and Chowdhury, 1995; Khandker, Samad and Khan, 1998; Rosintan and Cloud, 1999; Latifee, 2003; Kuiper and Ree, 2005; Dunn, 2005; and Panda, 2009). As mentioned by Rosintan and Cloud (1999) poor and hardcore poor women all over the world, with access to productive capital offered by MFO's (Microfinance Organizations) created their own employment in small scale agriculture and dairying, food processing and sales, beer brewing, midwifery, crafts, services, and petty trading. Because of the importance of self and wage employment, the government and non-government organizations focused on intermediary programs like microcredit programs to provide small scale working capital and training to the poor and hardcore poor households, who needed the service most.

Microcredit was originally established to bridge the capital gap in fact unfilled by the rural cooperatives and commercial banks. It is a collection of banking practice built to provide small loans and accepting small saving deposits. According to Otero (1999), microcredit provides access to productive capital, which enables poor self-employed people to create productive capital, to protect the capital they have, to deal with risk and to avoid the loss of capital. The beginning of microcredit in Bangladesh is one of the most important innovations in the development policy in last fifty years (Guttman, 2007). The most famous and successful microcredit methodology was started as an action research project, launched in 1976 by Professor Mohammad Yunus in Bangladesh. The result was the establishment of the Grameen Bank, which extended credit and banking facilities to the poor in Bangladesh and many other countries (Uotila, 2005). Grameen banks microcredit model was replicated by many other NGOs (non-government organization) around the world, and Amanah Ikhtiar Malaysia (AIM) is one of them. 
The poverty and unemployment rate in Malaysia has declined dramatically after its independence. While $49.3 \%$ of Malaysian households lived below the poverty line in 1970, the poverty rate has reduced significantly to $16.5 \%$ in 1990, and further declined to $3.6 \%$ in 2007 . The unemployment rate also followed the same pattern. While 5.6\% of the total labor force (15 to 64 years old) was unemployed in 1984, but this figure increased in the following years $7.4 \%$ in $1986,7.3 \%$ in 1987 and $7.3 \%$ in 1988 . However, the unemployment rate was consistently below $4 \%$ in the years from 1995 to 2009 . The reduction of poverty and unemployment rate can be attributed to the rapid economic growth in Malaysia which generated higher-paid employment opportunities and profitable micro and small-scale businesses opportunities (Economic Report, 2008). Moreover, the government of Malaysia undertakes several strategies to increase productivity, diversify sources of income and improve the quality of life of the poor. These poverty and unemployment reduction strategies are the integral part of Malaysia's core development plans. The government encourages and works together with private sectors and non-government organizations (NGO) to reduce poverty and unemployment. Malaysia's projects under the development program for the hardcore poor provide assistance to two NGO's; namely, Yayasan Basmi Kemiskinan (Poverty Eradication Foundation) and Amanah Ikhtiar Malaysia (AIM). Among them, the most active one, AIM uses the group based Grameen Bank (a Bangladeshi microfinance organization) model and provides collateral free credit to poor and hardcore poor households in order to improve their socio-economic conditions as well as reduce unemployment and poverty rate in Malaysia.

AIM started as an applied research project and then institutionalized as a registered private trust in 1987. As at March 2008, AIM outreached to a total of 183,901 clients with $98 \%$ of repayment rate. AIM selects their clients based on clients' gross average monthly household income. Households with gross monthly household income below the poverty line income (PLI - has been calculated by the Malaysian government since 1976. It was estimated based on the necessity of food and other basic needs.) would be considered as absolute poor, while households with gross monthly household income below half of the PLI would be categorized as hardcore poor. AIM only selects those households, whose gross monthly household income falls below the PLI, which includes both poor and hardcore poor households.

In assisting the poor (including the hardcore poor), AIM provides small amount of credit without any collateral. Moreover, no legal action would be taken if the borrowers fail to settle their payments. AIM's microcredit approach is based on small repayment system to be paid on weekly basis through center meeting. Although the primary objective of AIM's microcredit schemes is to provide loans for income generating activities (namely I-Mesra loan, I-Srikandi loan and I-Wibawa loan), AIM does provide loans for other activities such as recovery loan (I-Penyayang), education loan (I-Bistari) and housing/multipurpose loan (I-Sejahtera). As at March 2008, AIM has extended their outreach to 69 branches in eight states in Malaysia and these branches cover a total of 3,745 villages. There are 42,297 groups in 4,919 centers, currently serving a total of 183,901 clients.

Despite positive impacts of microcredit many researchers question the efficacy of microcredit in reducing the poverty and unemployment rate among the hardcore poor households (Hasan, 2003; Hashemi, 1997; Rahman, 1998; and Datta, 2004). The small amount of working capital provided by MFO's are commonly invested in small scale businesses and these businesses operate on a small scale, without any paid stuff and with few assets. With low capital and no specialized skills, these businesses are operating arenas of low entry requirements and high competition, therefore have low productivity and unable to reduce poverty rates among hardcore poor households. As mentioned by Snodgrass and Sebstad (2002), the benefits that people gain from borrowing and saving money depend on the uses they can make of these funds. Households' ability to generate income or grasp employing generating opportunities is not the same among all levels of poor. CGAP (2006) in their "Good practice guideline" mentioned that, "widespread experience with microcredit has found that it can even harm the poor who do not have capacity to absorb debt." Although many MFO's often talk about pro-poor development strategy, many researchers showed that moderate poor not the hardcore poor, are receiving the service and enjoying the benefits of microcredit.

The microcredit schemes and training provided by AIM promote self-employment among the poor, mostly unemployed women with part-time family obligation, for whom income stabilization is more important than enterprise growth. Even though it was well documented in the literature that microcredit program may not create many new jobs, but they can improve the quality of self-employment for the poor and hardcore poor micro-entrepreneur. Given that there was no known attempt so far by AIM or any external researcher to measure the impact of microcredit schemes on employment, this study intends to measure the impact of AIM's microcredit schemes on employment among hardcore poor households in Peninsular Malaysia. 


\section{Impacts of Microcredit}

Nearly three billion poor people around the world do not have access to basic financial services (Abed, 2000). Microcredit, as defined by Robinson (2001), is a "small scale financial services - primarily credit and savings provided to people who farm, fish or herd". The most common financial services offered by microfinance organizations (MFO) includes savings, microcredit, payment and transfer services, and insurance. Microcredit service is commonly provided by NGOs, savings and credit cooperatives, private and state owned banks, postal banks, members owned community organizations, non-bank intermediaries, such as finance or insurance companies, and other financial organizations. Products and services of microcredit programs are targeted to the poor and hardcore poor households, who make up nearly half of the total population of the world (Abed, 2000). Study by Hossain (1988) noted that the most direct effect of microcredit has been on the accumulation of capital by the poor. The amount of working capital employed by clients' enterprises was increased by an average of three times within a period of 27 months. The investment in fixed assets was about 2.5 times higher for borrowers with more than three years' membership than for those who joined during the year of the survey. Hossain (1988) also pointed out that about one third of the members were unemployed before they joined microfinance program. With loans, these members involved in self-employment activities and the resulting effects on income were impressive.

Few years later, in their impact study Neill et al. (1994) conducted a 22 percent increase in employment rate among K-REP clients in Kenya. Khandker and Chowdhury (1995) conducted a study on Grameen bank's clients in Bangladesh, noted that the increase in self-employment among the poor with access to credit has resulted in an increase in rural wages. Khandker, Samad and Khan (1998) mentioned that microcredit program have positive impact on income, production and employment particularly in rural non-formal sector. Latifee (2003) in his study on Grameen Banks clients mentioned that participation in microcredit program reduced unemployment rate among clients, and made a positive contribution to their standard of living. Study conducted by Dunn and Arbuckle (2001) in Peru found on average nine days of extra employment per months, where approximately 40,000 clients have over 4.3 million workdays per year, or the equivalent of 17,414 full-time jobs, of which 6,259 are paid positions for non-household members. Dunn (2005) conducted an impact study in Bosnia and Herzegovina, also found a positive impact of microcredit on respondents and their household's income, employment, business investment, business registration and post-war transition. Panda (2009) in his study conducted in India noted a significant increase in borrowers household income (11.41 percent), asset position was 9.75 percent higher than non participants and savings increased by 42.53 percent. This study also found an increase in annual employment days among the clients.

The impact of AIM's microcredit schemes follows a similar pattern, as it does for other microfinance organizations all over the world. The first internal impact study conducted by Gibbons and Kasim (1990) discovered a significant increase of client's monthly household income from an average of Ringgit Malaysia (RM) 142 per month prior to participation to RM220, a 55\% increase in monthly household income. The second internal impact study in 1990, showed further overall improvement among participating households. Around 98\% of them experienced an increase in household income compared to $70 \%$ from the first study. The pilot branch recorded an $88 \%$ increase in household income compared to the previous study where newer branches recorded only $56 \%$ increase. An overall increase was $77 \%$ compared to $45 \%$ previously, with an average increase of RM4668 per year or RM391 per month. The per capita monthly income also increased from RM40 to RM73. The findings echoed the earlier study.

In mid-1990, Malaysian government initiated an impact assessment study on AIM's microcredit schemes by a team from Social Science and Economic Research Unit (SERU) of the Prime Ministers Department. Findings from SERU's impact study reconfirmed the findings of the first two impact studies. This study noted that the overall household income was more than doubled (from RM197.78 per month to RM465.66 per month) after participating in AIM's microcredit schemes. SERU also measured the impact on quality of life, by analyzing the ownership and quality of housing, type and quality of household assets, agricultural land and savings. Increase in household income enabled the participants to improve their housing conditions. Household savings increased from an average of RM33.11 to RM211.25. The increase in household income also facilitated an increase in expenditure on food, nutrition, education and reinvestment. As for cost effectiveness, with an operating cost of RM7, 056, AIM managed to release 249 poor families from poverty.

Another impact study was conducted by AIM's research and development unit in 1991/93 and the findings reconfirmed the trends in non-monetary impact of microcredit on poor household, of the earlier studies. This study showed an improvement in the owner occupied house to $85 \%$ compared to $80 \%$ prior to participating AIM's microcredit schemes. The use of electric household products also showed some slight improvements. On 
the perception of nutritional quality, $58 \%$ felt there was an improvement, $34 \%$ felt no change and the remainder were not sure about it. This study also showed that a $13 \%$ increase in household income with an average RM309 per month bringing it to RM532 compared to RM223 before participation. This study found a direct positive relationship between level of income and utilization of loans, the more loans being utilized, the higher the income. In 1994, AIM provided funds to Center of Policy Research, University Sains Malaysia; to conduct an external impact study. The findings showed that among non-participating poor, $77 \%$ of them are still under poverty line. Among them, $32.7 \%$ are at the bottom half; and only $23 \%$ managed to escape out of poverty without microcredit. On the other hand, among 244 active and inactive members and dropouts, $57 \%$ of them were no longer poor, $33 \%$ of them were moderately poor and $11.5 \%$ were still at the bottom half of the national poverty line. Findings from Salma (2004) showed that the household income, expenditure, savings and assets increased for both AIM and PPRT participants compared to non-participants. Furthermore, these increases are higher for AIM clients than PPRT clients. Salma (2004) therefore concluded that the microcredit program has direct and higher contribution to generate income than non microcredit program like PPRT.

\section{Theoretical Framework and Research Hypothesis}

Socio-economic development is a complex process of social and economic development, which in regard of assessment of the impact of microcredit, is demonstrated by using social capital theory, human capital theory, access to finance and a conceptual model named 'household economic portfolio model'.

Social capital is the sum of the actual and potential resources embedded within, available through, and derived from the network of relationships possessed by an individual or social unit (Nahapiet and Ghoshal, 1998). AIM's group based microcredit model allows every client to assemble in a weekly center meeting, where clients exchange information and ideas with AIM officials. This enforced weekly center meeting can improve client's social networking and bondage; therefore can be an important source of social capital. This improved social bondage, as per social capital theory, can improve clients and their household member's ability to grasp income and employment generating opportunities. Human capital is the knowledge and skills people accumulate through formal instruction, training and experience that facilitate the creation of personal, social and economic well-being (Becker, 1993). The importance and effect of training programs to improve household's abilities to take advantages of income generating opportunities was addressed by almost every studies measuring the performances of microcredit program (Naved, 1994; Otero, 1999; Zaman, 1999; Pitt, Khandker and Cartwright, 2003; Matin and Begum 2003; and Rahman, Rafiq and Momen, 2009). AIM provides a wide range of training in order to improve their client's ability to find new income generating activities. They assist in the selection of appropriate income generating activities for the clients making sure that the loan are suitably used and they also assist in improving the clients' money management skills.

Modern development theory studies the evolution of growth and income inequalities where access to finance plays a very critical role. As mentioned by Claessens and Tzioumis (2006), lack of access to finance can be the critical mechanism for generating persistent income inequality or poverty traps, as well as lower growth. Access to finance increases clients and their household's ability to increase income generating opportunities and employment opportunities, which ultimately leads to increase household income and asset. Measuring the impact of AIM's microcredit program on hardcore poor household's income therefore strengthens the underlying assumptions of access to finance where it is expected that access to working capital will lead to an increase in poor household's ability to grasp employment generating opportunities in Peninsular Malaysia.

As mentioned by Hulme (1997), "behind all microfinance programs is the assumption that intervention will change human behaviors and practices in ways that will lead to the achievement (or raise the probability of achievement) of desired outcomes." The conceptual model of impact chain presents a complex set of links as each 'effect' becomes a 'cause' in its own right generating further effects. One of the most complex conceptual models for impact assessment was presented by Chen and Dunn (1996), called Household Economic Portfolio Model (HHEP). The researchers confirmed the usefulness of HHEP model in addressing the fungibility and attribution issues. The key advantages of HHEP model is that, it helps in the formation of research design and hypothesis. Both HHEP model developed by Chen and Dunn (1996) and modified HHEP model by Uotila (2005) have many implications for microfinance impact analysis and this research model is based on those implications.

In this research, hypotheses were used to test few implications of the HHEP model. The objective of this study is to measure how microcredit program offered by AIM affects employment status among hardcore poor clients and their communities in Peninsular Malaysia. In support of the research objective, the following specific alternative hypotheses are investigated:

1) Hypothesis $1\left(\mathrm{H}_{1}\right)$ : There is an association between household members' employment status (employed or 
not-employed) and respondents' status. It is expected that a relatively higher percentage of old respondents employed household members in their main economic activities than that of new respondents.

2) Hypothesis $2\left(\mathrm{H}_{2}\right)$ : There is a significant difference in mean number of household members employed by new and old respondents. It is expected that the mean number of household members employed by old respondents' households are significantly higher than that of new respondents.

3) Hypothesis $3\left(\mathrm{H}_{3}\right)$ : There is an association between non-household members' employment status (employed or not-employed) and respondents' status. It is expected that a relatively higher percentage of old respondents employed non-household members in their main economic activities than that of new respondents.

4) Hypothesis $4\left(\mathrm{H}_{4}\right)$ : There is a significant difference in mean number of non-household members employed by new and old respondents. It is expected that the mean number of non-household members employed by old respondents' households are significantly higher than that of new respondents.

5) Hypothesis $5\left(\mathrm{H}_{5}\right)$ : There is a significant difference in mean number of gainfully employed members among new and old respondents households. It is expected that the mean number of gainfully employed members among old respondents' households are significantly higher than that of new respondents.

\section{Research Design}

This research employed a cross-sectional design with stratified random sampling. Samples were selected from three different geographic areas from three states namely Kedah, Kelantan and Terengganu in Peninsular Malaysia. These three states were randomly selected from the bottom six states (poverty rates were relatively higher in these six states) of Peninsular Malaysia. AIM offered financial services to the poor and hardcore poor households through a total of 28 branches in three selected states. Most of these branches are located in very small towns or rural areas, as the poverty rate in isolated rural areas are expected to be much higher than in urban areas. Among these 28 branches, this study randomly selects three branches from each state. The selected three branches were in Baling, Kedah; Pasir Puteh, Kelantan and Setiu, Terengganu. All data were collected from these three branches.

The sampling methodology was designed to compare two groups of clients, where both groups were selected from AIM's client base. Therefore, instead of external control group, this study selects new clients (number of months as clients was less than 24 months) as control group and old clients (number of months as clients were between 48 months to 72 months) as treatment group based on the number of months they participated with AIM. All the clients were first selected based on number of months as client and then selected again based on pre-AIM household income. Clients with pre-AIM household income below half of the joining years PLI were the hardcore poor clients. 2779 clients participated in this program in all three branches for the selected period. Among them, a total of 505 clients or around $18 \%$ of the 2779 clients were hardcore poor and among these 505 clients, 22 clients or around $4.36 \%$ clients dropped out from the program. This study then collected data from AIM's client's record book. Data about 483 hardcore poor new and old clients' current unpaid debt, pre-AIM household income, joining date, total amount clients saved in AIM, total amount of credit received from each scheme and the total amount of credit received, were collected.

In the second stage of data collection, researcher explained the purpose of this study and asked these 483 selected clients for their permission to interview them. Among the 483 clients, 386 clients agreed to participate in the interview after their weekly center meeting, among them 184 were old clients and 202 were new clients. Among these 386 clients, 45 clients mentioned that they received credit from other sources after they joined AIM's microcredit program, and 8 clients did not answer all the questions because of their personal reasons. This study then excluded clients who received credit from other sources and clients who did not answer all the questions, and collected complete data from a total of 333 hardcore poor clients, among them 161 were old clients and 172 were new clients.

However, there are some obvious limitations in terms of cross-sectional design. Firstly, it is likely that self selected clients, already share certain types of characteristics (like entrepreneurship), not necessarily shared by the population in general. Secondly, if data is collected only from the active members, the sample will be biased because data is only collected from the clients who are still participating in AIM's microcredit programs, and therefore clients who already dropped out of the programs are not included. Given that the average dropout rate for both new and old clients was only $4.36 \%$; this study did not collect any data from dropouts. Moreover, since AIM outreached around 82\% poor and hardcore poor households in Malaysia, this research expected that the characteristics of new clients and eligible poor and hardcore poor non clients will be almost similar. In the data analysis, both the Shapiro-Wilk's test for normality and Levene test for homogeneity of variance were 
performed prior to the test of the research hypothesis. Since the assumptions were not fulfilled, this study therefore used the non-parametric Mann-Whitney test to measure the mean difference. This study also used Pearson's chi-square test to measure association between dependent and independent variables.

\section{Research Findings}

\subsection{Adult Household Members Employment Status}

Table 1 presents the employment status of the adult (falling with in the age of 15 years to 64 years) household members of new and old respondents. In the total 333 households, there are 913 adult members. Among them, 451 members or $49.40 \%$ of total household members are gainfully employed; 224 household members or about $25 \%$ of them are occupied with domestic work only; 20 household members or about $2.2 \%$ of them are unemployed; 26 household members or $2.85 \%$ of the total adult members are unable to work; 73 adult household members or $8 \%$ of total adult members are studying; and 119 household members or $13.03 \%$ of total household members are working for food. There is a relatively higher percentage of adult household members of all old respondents involved with 'gainfully employed' and 'studying' activities, compared to adult household members of all new respondents.

\subsection{Testing Hypothesis 1}

As presented in Table 2, out of total 333 respondents' households, only 59 households, or $17.7 \%$ of total respondents households reported that they employed household members in their economic activities. Out of 59 households only 9 of them are new respondents and 50 of them are old respondents. The percentage of households employing household members in their income generating activities among old respondents is $31.1 \%$, which is much higher compared to new respondents. The p-value for Pearson's chi-square test is 0.000 , which is less than the chosen $\alpha$ level of 0.05 , which indicates that household member's employment status (employed or not employed) is associated with respondent's status - new and old. Table 2 also shows a relatively higher percentage of old respondents employing their household members in income generating activities than new respondents.

\subsection{Testing Hypothesis 2}

The mean and standard deviation of the number of household members employed by old, new and all respondents are presented in Table 3. The mean number of household members employed by old respondents is higher than that of new respondents. The p-value for Shapiro-Wilk test of normality is less than 0.05 ; therefore, the normality assumption is violated. The p-value for the Levene's test of homogeneity of variances is 0.939 , indicating that the variability in the distribution of number of household members employed by the two groups is not statistically significant. A non-parametric test, the Mann-Whitney test was therefore conducted. The p-value for Mann-Whitney test is 0.689 , which is more than the chosen $\alpha$ level of 0.05 , indicating an insignificant difference in the mean number of household members employed by new and old respondents in their main household economic activities.

\subsection{Testing Hypothesis 3}

The number and percentage of 'non-household members' employed by respondents in their economic activities is presented in Table 4 below. Of the 333 respondent's households, 63 of them employed non-household members. $32 \%$ of the total old respondent's households employed non-household members in their income generating activities compared to only $6.4 \%$ for new respondents. The p-value for Pearson's chi-square test is 0.000 , which is less than 0.05 , indicating that employment status (employed or not employed) is associated with respondent's status - old and new. From the table, it is noted that participation of AIM's microcredit schemes leads to increase employment opportunities in the community.

\subsection{Testing Hypothesis 4}

The mean and standard deviation of number of non-household members employed by the new and old respondents in their main household economic activities are presented in the Table 5. The mean number of non household members employed by old respondent's households is higher than new respondent's households. The p-value for Shapiro-Wilk test of normality for both groups is less than 0.05 ; therefore, the normality assumption is violated. A non-parametric test, the Mann-Whitney test was therefore conducted. The p-value for the Mann-Whitney test is 0.014 , which is less than the chosen $\alpha$ level of 0.05 , indicating a significant difference in the mean number of non-household members employed by new and old respondents in their main household activities. Old respondents employed a significantly higher number of non-household members in their main household economic activities. This indicates that participation in AIM's microcredit program has led to an increase in the employment rate in the respondent's communities in Peninsular Malaysia. Among the 
respondent's households who employed non-household members in their main economic activity, most of them employed non-household members as wage worker (74.60\%). Only $14.29 \%$ of the respondent's households employed non-household members as salaried workers and $11.11 \%$ respondent's households employed non-household members as working for food.

\subsection{Testing Hypothesis 5}

Out of the total 333 respondents households there are 913 adult household members. Among these 913 household members, 451 members are gainfully employed. 259 out of 451 gainfully employed household members are from old respondents households. As presented in the Table 7, the mean number of gainfully employed household members among old respondents is 1.61 members with a standard deviation of 0.69 members. On the other hand, 192 out of total 451 gainfully employed household members are from new respondents households. The mean number of gainfully employed members among new respondent's households is 1.12 members with a standard deviation of 0.34 members. The p-value for the Shapiro-Wilk test of normality for both groups is less than 0.05 , which indicates that the normality assumption is violated. However, the p-value for Levene's test is 0.000 , indicating a significant difference in the variability on the number of gainfully employed members among old and new respondents. Since the normality assumption is violated, a non-parametric Mann-Whitney test was therefore conducted. The Mann-Whitney test gives a p-value of 0.000, which is less than the chosen $\alpha$ level of 0.05 , indicating a significant difference in the mean number of gainfully employed household members among new and old respondent's households. The mean number of gainfully employed household members in old respondent's households is significantly higher than that of new respondents. Therefore, this study concludes that participation in AIMs microcredit program leads to an increase in 'number of gainfully employed members' in client's households.

\section{Conclusion and Recommendations}

As mentioned by Kuiper and Ree (2005) from International Labour Office, Geneva, that "nothing is more fundamental to poverty reduction than employment". Microcredit organizations all over the world provide small amount of working capital to promote self-employment for people who are excluded from the services offered by commercial banks. Since the self employed poor commonly have no specialized skills and operate in arenas with low entry barrier and high competition, followers of Grameen Banks' group based microcredit model includes Amanah Ikhtiar Malaysia also provide training in order to improve micro-enterprise management skills as well as enable their clients to take advantages of income and employment generating opportunities. The weekly meetings among the clients and officials also improve the social bonding among clients and they also increase employment generating opportunities among client's household members.

Findings of this study indicate that a relatively higher percentage of total adult household members among old respondents are gainfully employed and the mean numbers of gainfully employed members among the old respondents' households are significantly higher than that of new respondents. This clearly indicates that participation in AIM's microcredit program increases employment rate among client's households. A relatively higher percentage of old respondents also employed household and non household members in their income generating activities. The mean number of non household members employed by old respondents is also significantly higher than that of new respondents which indicates participation in AIM's microcredit program also increases employment generating opportunities at community level. These findings are consistent with the earlier studies conducted to measure the impact of microcredit on employment. Although researchers argue about the affect of self-employment on income, which may not be higher than wage income, for most of the microcredit clients self employment provide the flexibility to manage domestic and work duties. Most of the self employed women prefer self employment because of its flexibilities which allow them to better balance work and family responsibility. In order to improve the economic status of women during the development process, AIM should therefore focus on designing a flexible credit policy and appropriate training programs to enable the poor and hardcore poor clients to increase the employment rate and decrease poverty.

\section{References}

Abed, H. F. (2000). Microfinance NGOs in Bangladesh Growth, Impact and Challenges. Paper presented at the Asian Regional Conference jointly organized by INASIA and CDF on "The Potential and Limitations of Economic Initiatives in Grassroots Development - Current Issues and Asian Experiences" from 27th-30th November 2000.

Amanah Ikhtiar Malaysia. (1990). Internal Impact Study (Second). Research and Development Unit

Amanah Ikhtiar Malaysia. (1991-1993). Internal Impact Study (Third). Research and Development Unit 
Becker, G. (1993). Human capital: a theoretical and empirical analysis, with special reference to education. Chicago: The University of Chicago Press.

CGAP. (2006). Good Practice Guideline for the Funders of Microfinance. CGAP. [Online]. Available: http://www.cgap.org/gm/document-1.9.2746/donorguidelines.pdf (12.11.2008)

Chen, M.A. and Dunn, E. (1996). Household Economic Portfolios. AIMS Project. Washington, D.C.: Management Systems International.

Claessens, S. and Tzioumis, K. (2006). Measuring firms' access to finance, World Bank, Washington DC.

Datta, D. (2004). Microcredit in Rural Bangladesh: Is It Reaching the Poorest? Journal of Microfinance. Vol: 6 Pp: 55-81.

Dunn, E. (2005). Impact of Microcredit on Clients in Bosnia and Herzegovina, Foundation for Sustainable Development of the Federation of Bosnia and Herzegovina and Republika Srpska Development and Employment Foundation.

Dunn, E. and Arbuckle, J. G. Jr. (2001). The impacts of Microcredit: A Case Study from Peru, Assessing the Impact of Microenterprise Services (AIMS), Management Systems International, Washington, D.C.

Gibbons, D. S. and Kasim, S., (1990). Banking on the Rural Poor, Center for Policy Research, University Science Malaysia, Malaysia

Guttman M.J. (2007). Repayment Performance in Microcredit Programs: Theory and Evidence, Working Paper-11, Networks Financial Institute, Indiana State University. USA.

Hasan, M. E. (2003). Implication of Financial Innovations for Poorest of the Poor in the Rural Area: Experience from Northern Bangladesh. Journal of Microfinance. Vol: 5, Pp: 56-78.

Hashemi, S.M. (1997). Dropouts and Leftouts: The Grameen Targeting of the Extreme Poor. Dhaka: Credit Development Forum.

Hossain, M. (1998). Credit for the Alleviation of Rural Poverty: The Grameen Bank in Bangladesh. Research Report No. 55, IFPRI, Washington, D.C.

Hulme, D. (1997). Impact Assessment Methodologies for Microfinance: A Review. This paper was prepared for CGAP's Working Group on Impact Assessment, Washington D.C.

Khandker, S.R. and O.H. Chowdhury. (1995). Targeted Credit Programs and Rural Poverty in Bangladesh. World Bank, Washington, W.C.

Khandker, S. R., Samad, A. H. and Khan, H. Z. (1998). Income and Employment Effects of Micro-credit Programmes: Village-level Evidence from Bangladesh. The Journal of Development Studies, Vol:35, No:2. Pp.96-124.

Kuiper, M. and Ree, K.V.D. (2005). Growing out of poverty: How employment promotion improves the lives of the urban poor; SEED Working Paper No. 74; International Labour Office · Geneva; 2005.

Latifee, H. I. (2003). Microcredit and Poverty Reduction, International Conference on Poverty Reduction through Microcredit. Taksim-Istambul, June 09-10, 2003.

Matin, I. and Begum, A. S. (2003). Asset-ing the Extreme Poor: Experiences and Lessons from a BRAC Project, Research and Evaluation Division, Bangladesh Rural Development Committee, Dhaka, Bangladesh.

Nahapiet, J. and Ghoshal, S. (1998). Social Capital, Intellectual Capital, and the Organizational Advantage. Academy of Management Review. Vol: 23. Issue: 2

Naved, R. (1994). Empowerment of Women: Listening to the Voices of Women, The Bangladesh Development Studies, 'Special Issue on Women, Development and Change' Vol. 22, Issue. 2, Pp. 121-155

Neill, C., Davalos, M. Kiiru, W., Manundu, M., and Sebstad, J. (1994). The Kenya Rural Enterprise Programme under Cooperative Agreement, GEMINI Technical Report No. 77. Bethesda, MD.

Otero, M. (1999). Bringing Development back into Microfinance. Journal of Microfinance. Vol:1, Issue: 1.

Panda K. D. (2009). Participation in the Group Based Microfinance and its Impact on Rural Households: A Quasiexperimental Evidence from an Indian State, Global Journal of Finance and Management, Vol: 1, No: 2, Pp: 171-183.

Pitt, M., Khandker, S. and Cartwright, J. (2003). Does Micro-Credit Empower Women? Evidence from Bangladesh; World Bank Policy Research Working Paper 2998. Washington D.C. 
Rahman, H.Z. (1998). Bangladesh: Dynamics of rural poverty. Paper presented at International Conference on Poverty, Dhaka, Bangladesh. 9/11 February 1998.

Rahman, S., Rafiq, R. B. and Momen, M. A. (2009). Impact of Microcredit Programs on Higher Income Borrowers: Evidence from Bangladesh. International Business \& Economics Research Journal, Vol-:8, Issue: 2.

Robinson, M. (2001). The Microfinance Revolution: Sustainable Finance for the Poor. World Bank. Washington, D.C.

Rosintan D. M. P. D., and Cloud K. (1999). Gender, self-employment and microcredit programs: An Indonesian case study. The Quarterly Review of Economics and Finance. Vol: 39. Pp:769-779

Salma M. A (2004). Comparative Case Study on Outreach and Impact of Ikhtiar Loan Scheme and Special Program for Hardcore Poor in Seberang Perai Pulau Pinang. University Sains Malaysia.

SERU (1990). Impact Study. Prime Ministers Department, Malaysia.

Snodgrass, D.R. and Sebstad, J. (2002). Client in Context: The Impact of Microfinance in three countries, Consultative Group to Assist the Poor, Washington DC: Management Systems International

Uotila, A. (2005). Livelihood Impact of Microfinance access for the Poor: The Case of Vision FINCA Rwanda. The University of Guelph, Canada.

Zaman, H. (1999). Assessing the Impact of Micro-credit on Poverty and Vulnerability in Bangladesh. Policy Research Working Paper. Development Economics, the World Bank, Washington D.C., USA.

Table 1. Adult Household Member's Employment Status

\begin{tabular}{|l|l|l|l|l|l|l|}
\hline \multirow{2}{*}{$\begin{array}{l}\text { Household Members } \\
\text { Employment Status }\end{array}$} & \multicolumn{2}{l|}{ New Respondents } & \multicolumn{2}{l|}{ Old Respondents } & \multicolumn{2}{l|}{ Total Respondents } \\
\cline { 2 - 7 } & Count & $\%$ & Count & $\%$ & Count & $\%$ \\
\hline Gainfully Employed & 192 & $43.64 \%$ & 259 & $54.99 \%$ & 451 & $49.40 \%$ \\
\hline Domestic Work & 122 & $27.73 \%$ & 102 & $21.66 \%$ & 224 & $24.53 \%$ \\
\hline Unemployed & 14 & $3.18 \%$ & 7 & $1.27 \%$ & 20 & $2.19 \%$ \\
\hline Unable to Work & 17 & $3.86 \%$ & 9 & $1.91 \%$ & 26 & $2.85 \%$ \\
\hline Studying & 31 & $6.82 \%$ & 43 & $9.13 \%$ & 73 & $8.00 \%$ \\
\hline Working for Food & 65 & $14.77 \%$ & 52 & $11.04 \%$ & 119 & $13.03 \%$ \\
\hline Total & 441 & $100.00 \%$ & 472 & $100.00 \%$ & 913 & $100.00 \%$ \\
\hline
\end{tabular}

Table 2. Employment of Household Members

\begin{tabular}{|l|l|l|l|l|}
\hline \multicolumn{2}{|c|}{} & New Respondents & Old Respondents & Total Respondents \\
\hline \multirow{3}{*}{ Employed } & Count & 9 & 50 & 59 \\
\cline { 2 - 5 } & $\%$ & $5.2 \%$ & $31.1 \%$ & $17.7 \%$ \\
\hline \multirow{3}{*}{ Not Employed } & Count & 163 & 111 & 274 \\
\cline { 2 - 5 } & $\%$ & $94.8 \%$ & $68.9 \%$ & $82.3 \%$ \\
\hline \multicolumn{2}{|l|}{ Pearson Chi-Square test, $\mathrm{r}=38.038, \mathrm{df}=1, \quad \mathrm{p}$-value $=0.000<0.05$} \\
\hline
\end{tabular}

Table 3. Number of Household Members Employed

\begin{tabular}{|l|l|l|l|}
\hline & New Respondents & Old Respondents & Total Respondents \\
\hline $\mathrm{N}$ & 9 & 50 & 59 \\
\hline Mean & 1.22 & 1.20 & 1.20 \\
\hline Standard Deviation & 0.44 & 0.49 & 0.48 \\
\hline Mann-Whitney Test, Asymp. Sig. (2-tailed) $=0.689$ & \\
\hline
\end{tabular}


Table 4. Employing Non-Household Members

\begin{tabular}{|l|l|l|l|l|}
\hline \multicolumn{2}{|c|}{} & New Respondents & $\begin{array}{l}\text { Old } \\
\text { Respondents }\end{array}$ & $\begin{array}{l}\text { Total } \\
\text { Respondents }\end{array}$ \\
\hline \multirow{3}{*}{ Employed } & Count & 11 & 52 & 63 \\
\hline \multirow{3}{*}{ Not Employed } & $\%$ & $6.4 \%$ & $32.3 \%$ & $18.9 \%$ \\
\hline Pearson Chi-Square test, $r=36.374, \mathrm{df}=1, \quad \mathrm{p}$-value $=0.000<0.05$ & 109 & 270 \\
\cline { 2 - 5 } & Count & 161 & $67.7 \%$ & $81.1 \%$ \\
\hline
\end{tabular}

Table 5. Number of Non-Household Members Employed

\begin{tabular}{|l|l|l|l|}
\hline & New Respondents & Old Respondents & Total Respondents \\
\hline $\mathrm{N}$ & 11 & 52 & 63 \\
\hline Mean & 1.45 & 2.37 & 2.21 \\
\hline Standard Deviation & 0.68 & 1.28 & 1.25 \\
\hline \multicolumn{2}{|l}{} \\
\hline
\end{tabular}

Table 6. Employment Status

\begin{tabular}{|l|l|l|l|l|l|l|l|}
\hline \multirow{2}{*}{ Employment Status } & \multicolumn{2}{|l|}{ New Respondents } & \multicolumn{2}{l|}{ Old Respondents } & \multicolumn{2}{l|}{ Total Respondents } \\
\cline { 2 - 7 } & Count & $\%$ & Count & $\%$ & Count & $\%$ \\
\hline Salaried Work & 2 & $3.18 \%$ & 7 & $11.11 \%$ & 9 & $14.29 \%$ \\
\hline Wage Work & 9 & $14.28 \%$ & 38 & $60.32 \%$ & 47 & $74.60 \%$ \\
\hline Working for Food & 0 & $0.0 \%$ & 7 & $11.11 \%$ & 7 & $11.11 \%$ \\
\hline Total & 11 & $100 \%$ & 52 & $100 \%$ & 63 & $100 \%$ \\
\hline
\end{tabular}

Table 7. Gainfully Employed Household Members

\begin{tabular}{|l|l|l|l|l|l|l|}
\hline \multirow{2}{*}{$\begin{array}{l}\text { Number of Gainfully } \\
\text { Employed Members }\end{array}$} & \multicolumn{2}{l|}{$\begin{array}{l}\text { Old } \\
\text { Respondents }\end{array}$} & \multicolumn{2}{l|}{$\begin{array}{l}\text { Total } \\
\text { Respondents }\end{array}$} & \multicolumn{2}{l|}{ Respondents } \\
\cline { 2 - 8 } & Count & $\%$ & Count & $\%$ & Count & $\%$ \\
\hline 1 & 153 & $88.95 \%$ & 78 & $48.45 \%$ & 231 & $69.37 \%$ \\
\hline 2 & 18 & $10.47 \%$ & 71 & $44.10 \%$ & 89 & $26.73 \%$ \\
\hline$\geq 3$ & 1 & $0.58 \%$ & 12 & $7.45 \%$ & 15 & $3.90 \%$ \\
\hline Mean & 1.12 & & 1.61 & & 1.35 & \\
\hline Standard Deviation & 0.34 & 0.69 & & 0.59 & \\
\hline Mann-Whitney Test, Asymp. Sig. (2-tailed) $=0.000$ &
\end{tabular}

